УДК $37.01 ; 374.1 ; 378$.

Книш Інна Василівна

$\mathrm{PhD}$, доц. кафедри ДПД та українознавства

Сумський національний аграрний університет, м. Суми, Україна

ORCID ID 0000-0003-4194-1555

knysh_sumy@ua.fm

Кочубей Наталія Василівна

доктор філософських наук, професор, завідувач кафедри менеджменту та інноваційних технологій соціокультурної діяльності

Національного педагогічного університету імені М. П. Драгоманова, м. Київ, Україна

ORCID ID 0000-0003-3668-7193

n.v.kochubey@ua.fm

\title{
ТЕХНОЛОГІЧНІ АСПЕКТИ СТАНОВЛЕННЯ НОВОЇ ОСВІТНЬОЇ ПАРАДИГМИ
}

\begin{abstract}
Анотація. 3'ясовано, що на постнекласичному етапі розвитку освіти в Україні склалися дві освітні парадигми, а саме: off-line освіта як система й on-line освіта як мережа, які мають свої переваги й недоліки. Обгрунтовано, що теоретико-методологічний дисбаланс, який виник між цими парадигмами, зумовив переосмислення Life Long Learning як нової освітньої моделі. Проаналізовано сучасні інноваційні техніки й методики, які використовуються у даних освітніх парадигмах. Доведено, що ІКТ - це засіб не поневолення, а звільнення, якого можна досягти завдяки створенню і поширенню нових антропопрактик, що мають на меті повернення людини не тільки до самої себе, а й до інших. Зазначено, що впровадження ІКТ має сприяти самоорганізації, самопізнанню та самовдосконаленню особистості як Учня (Студента), так і Вчителя (Викладача).
\end{abstract}

Ключові слова: нова парадигма освіти; Life Long Learning; IКТ; off-line освіта як система; on-line освіта як мережа; змішане навчання; Учень (Студент); Учитель (Викладач); антропопрактики; постнекласика.

\section{1. ВСТУП}

Постановка проблеми. Упровадження інноваційних технологій у різні галузі діяльності людини не оминуло й освітню. Про це свідчить пильна увага Міністерства освіти i науки України до інноваційних методів і методик, здатних забезпечити піднесення якості підготовки майбутніх високоосвічених фахівців. Одним із найбільш актуальних питань наразі залишається проблема співіснування двох освітніх парадигм: off-line освіти як системи й on-line освіти як мережі. Off-line освіта як система характеризується тим, що вона здебільшого спрямована на нав'язування i підпорядкування знань, що може спричиняти пригнічення ініціативи людини, яка навчається. On-line освіта як мережа, навпаки, перш за все, сприяє свободі вибору, розвитку ініціативності, когнітивної сфери, розширює коло спілкування, спонукає людину до самоосвіти впродовж усього життя тощо. Зауважимо, що між зазначеними освітніми парадигмами намітився теоретико-методологічний дисбаланс, що змушує фахівців 3 різних галузей науки шукати шляхи виходу 3 кризи і налагоджувати взаємозв'язки між ними. Одним 3 таких шляхів, на нашу думку, може стати впровадження новітніх технологій, методів і методик у навчальний процес.

Аналіз останніх досліджень та публікацій. Сутності розробки й упровадження інноваційних методів навчання в освітній процес присвячено праці як зарубіжних, так і вітчизняних учених, які пропонують: 
- загальнотеоретичні й науково-практичні проблеми розробки й упровадження інноваційних парадигм у сучасну освітню систему, окремі прогресивні форми, методи та технології навчання, досвід та перспективи їх використання в освітній практиці (Анатолій Алексюк, Борис Гершунський, Ірина Доброскок, Андрій Єршо́в, Мирослав Жалдак, Віктор Коцур, Васи́ль Кре́мень, Микола Лисенко, Юхим Машбиць, Вадим Монахов, Світлана Нікітчина, Володимир Ільїн, Сеймур Пейперт (Seymour Papert), Сергій Пролеєв, Тетяна Резнік, Ірена Роберт, Петро Саух та ін.);

- психолого-педагогічні методи (Юхим Машбиць, Андрій Савельєв, Ніна Тализіна, Володимир Тихомиров та ін.);

- специфіку викладання окремих дисциплін гуманітарного циклу, зокрема, історії та суспільствознавства (Олексій Румянцев, Андрій Чернов, Свгенія Полат);

- розробку i застосування педагогічних програмних засобів (ППЗ) (Єсен Бідайбеков, Сергій Григор'єв, Вадим Гріншкун, Сабир Каріев та ін.);

- створення й упровадженню on-line курсів (Валентин Биков, Марина Волкова, Леонтій Дериглазов, Володимир Кухаренко, Лариса Перхун, Ольга Рибалко, Гарі Розенблит, Наталія Сиротенко, Томас Петерсон, Ніна Товмаченко, Гаротт Хурадо та ін.); проблеми педагогічної інноватики (Ольга Абдалова, Інга Ісакова, Валентин Василенко, Ігор Галиця i Олександр Галиця, Ірина Мельник, Рaic Фатхутдінов, Олена Федоровська та ін.), які нове в освітньому процесі співвідносять 3 такими характеристиками, як корисне, прогресивне, позитивне, сучасне, передове.

Мета статті полягає у з'ясуванні механізмів упровадження і використання інноваційних технологій у двох освітніх парадигмах: off-line освіті як системі й on-line освіті як мережі, що зумовило появу нового розуміння Life Long Learning як нової парадигми освіти.

Необхідність досягнення зазначеної мети зумовила постановку і розв'язання таких дослідницьких завдань:

- проаналізувати особливості впровадження викладачами IКТ у off-line освіті як системі та on-line освіті як мережі, які спрямовані не тільки для набуття знань, умінь і навичок Учнів (Студентів), але i для розкриття освітніх компетенцій Учителя (Викладача) - якостей, що розвиваються в ході реалізації комплексу елементів освітньої діяльності;

- розглянути основні складові моделі змішаного навчання, які використовуються в сучасному освітньому середовищі: очне навчання (face-to-face); самостійне навчання (self-study learning); on-line навчання (on-line collaborative learning), та з'ясувати їх значення для модернізації сучасної освіти;

- довести, що ІКТ мають сприяти самоорганізації, самопізнанню та самовдосконаленню особистості як Учня (Студента), так і Вчителя (Викладача).

\section{2. ТЕОРЕТИЧНІ ЗАСАДИ ДОСЛІДЖЕННЯ}

Як зазначають Володимир Аршинов і Володимир Буданов, стрімке зростання складності, яке переживається нами сьогодні, й пов'язана 3 цим процесом невизначеність теперішнього i непередбачуваність майбутнього $\epsilon$ неминучим наслідком глобальної антропосоціотехнологічної (ко)еволюції, до якої залучено всю земну цивілізацію. Зростання складності й різноманітності - це засадничий принцип еволюції, біологічної, технологічної, соціальної та космологічної. Важливо наголосити, що одним із провідних чинників цього явища $\epsilon$ синергійна конвергенція знань, дослідницьких i проектних практик у галузі IKT, а також нанотехнологій, біотехнологій, когнітивних наук [1, с. 50]. 
3 огляду на цей процес сучасне суспільство з потребує якісної освіти, спроможної забезпечити потреби споживача й виробника матеріальних i духовних благ, що неухильно зростають. Перехід до інформаційного суспільства докорінно змінює становище освіти. Одним із провідних критеріїв щодо впровадження інноваційних технологій у освітній процес стає зміна психологічного, соціального, морального, економічного, політичного, юридичного тощо статусу самих Учнів (Студентів). Роман Рабінович [19], розглядаючи освітні технології для стартапів і системні рішення для нових форматів у освіті, пропонує вживати поняття: «off-line та on-line освіта». Розуміючи під терміном «парадигма» усталені теоретичні погляди, яких дотримуються та які визнають найбільш впливові представники наукового співтовариства, ми вважаємо за доцільне поширення такого потрактування і на процеси, що відбуваються на постнекласичному етапі розвитку освіти і виховання: off-line парадигма, на нашу думку, збігається 3 парадигмою освіти і виховання, характерною для їх розгляду як системи, a on-line - для освіти та виховання як мережі.

Як засвідчила практика, зазначають Василь Кремень і Василь Ткаченко, радянська система виявилася нездатною асимілювати інформаціоналізм із цілої низки посутніх причин, які випливали 3 природи тотального контролю з боку партії та КДБ над суспільними процесами, насамперед, інформаційними. На переконання бюрократичного керівництва, лише контроль міг забезпечити легітимність держави завдяки ії здатності маніпулювати населенням: використання друкарських машинок, які були рідкістю, і постачання паперу, як носія інформації, перебувало під суворим наглядом; доступ до машин для фотокопіювання вимагав допуску служб безпеки, входження до мережі міжнародних телефонних ліній і телекса теж був під контролем. Саме поняття «персональний комп'ютер» у свідомості бюрократичної верхівки вже руйнувало базові засади радянського устрою. «Отже, за своєю сутністю радянський етатизм відторгав розповсюдження інформаційних технологій, блокуючи тим самим процес спонтанної інновації шляхом використання мережевих взаємодій» [11, с. 10].

Такі процеси характерні не тільки для радянської системи, але і для інших країн. Наприклад, як зазначає Мануель Кастельс ((ісп. Manuel Castells Oliván), «виглядає цілком природним, що суспільні рухи та політичний процес використовували та використовуватимуть Мережу все більшою мірою 3 перетворенням Internet-y на головний інструмент діяльності, інформування, вербування, організації, домінування i контрдомінування. Кіберпростір стає конфліктною територією» [8, с. 165].

Сплив час, життя змінилося, суспільство «дерева життя» перетворилося на «ліс життя», й уже в «мережевому суспільстві» радикально змінюється людина, виникає такий собі антропологічний тренд [14, с. 89-114], а саме: самознищуються, зникають такі звичні для людського існування інститути, як сім'я, право, освіта, культура тощо, натомість на перший план виходять практики трансгресії, трансфігурації, суїцидальні практики й експериментування над собою, агресія зі знищенням середовища існування тощо. Отже, вочевидь відбувається своєрідна «еволюція людини» від Homo habilis (людина вміла) $\rightarrow$ Homo erectus (людина, яка рухається прямо) $\rightarrow$ Homo ergaster (людина, яка працює) $\rightarrow$ Homo sapiens (людина розумна) до Homo mobilis, «людини, яка сидить», - із мобільним телефоном, смартфоном, планшетом, комп'ютером або ноутбуком (рабом, кіборгом, мутантом, транс- або постлюдиною), тобто такої, яка замінює речі симулякрами та віртуальними двійниками, людей - персонажами, слова цифрами, голову - чипами, знання - компетентністю, формуючи Double World (другий світ) із «тілами без органів» [5] (для життя у комп'ютері органи не потрібні) й «тілами без простору» [13, с. 578] (на екрані об'ємів немає), яка постійно живе в мережі та доручає піклуватися про себе іншим, тобто йдеться про повне її зникнення перш за все як соціального виду. 
Нові предмети, що їх Жак Атталі (фр. Jacques Attali) називає «номадичними» [2] (від мобільних телефонів до мініатюрних модемів, що забезпечують підключення до світової інформаційної мережі з будь-якої точки планети), змінили і продовжують змінювати взаємини в усьому спектрі сучасного життя. Насамперед, вони вже змінили і продовжують змінювати ставлення людини до самої себе і до інших, перетворюючи їх на Homo mobilis. Антропологічна доля цивілізації Нomo mobilis, коли внаслідок розвитку техніки «людина почне створювати себе сама так, як вона створює товари, уявляється проблематичною. Цей процес вважається позитивним, проте він супроводжуватиметься втратою традиційної прихильності до країни, громади, родини.

3 появою глобального інформаційного павутиння над цим уже посталим територіальним/урбаністичним простором нашого світу утворився третій кібернетичний простір, елементи якого «позбавлені просторових вимірів, але вписані в єдину темпоральність стрімкого поширення. Із цього моменту людей не можна розділити фізичними перешкодами або тимчасовими відстанями. Опосередкована комп'ютерними терміналами й відеомоніторами відмінність між тут і там втрачає будь-який сенс» [26, с. 13].

Сучасний світ, як зауважує Володимир Аршинов, не тільки цілісний, він i складний. Життя за таких умов - це джерело інновацій, фрустрацій (наприклад, соціальні проблеми) [7, с. 165]. 3'являються нові професії і різновиди діяльності: аквізитор (лат. acquisitor - здобувач), андерайтер (англ. underwriter - гарант, страхувальник), івент-менеджер (англ. event - «подія», manage - керувати, очолювати), лайф-коучер (англ. life - життя, спосіб життя, coach - інструктувати, тренувати, напучувати), спічрайтер (англ. speech - промова, write - писати), сюрвеср (англ. survey - огляд, зйомка, межування), тітестер (англ. tee - чай, test - куштувати), трейдер (англ. trade - торгівля), хед-хантер (англ. head - голова, hunter - мисливець, hunt полювати); чоловік (дружина) на годину (ремонтні й господарські роботи в оселі) тощо. При цьому, як зазначає В. Лепський, постнекласична стратегія управління пов'язана 3 концептуальним рухом від «віртуального об'єкта» до «віртуального суб'єкта» [7, с. 166]. Так формується новий спосіб життя, з'являються нові звички, потреби, інтереси, цінності, тобто змінюється саме соціальне середовище людини; збільшується обсяг і кількість послуг/обов'язків (догляд за тваринами, виховання дітей, ремонт помешкання, автівки, побутової техніки тощо), які вона перекладає на плечі інших.

Усе це призводить до того, що людина змінюе і переоріснтовує свої базові навички й уміння. На підтвердження наведемо кілька проявів нового явища в культурі - аутсорсингу (від англ. outsourcing (outer-source-using) - використання зовнішнього джерела i/aбо ресурсу): ми не рахуємо подумки, а користуємося калькуляторами; не пишемо, а друкуємо на клавіатурі; не запам'ятовуємо інформацію, а занотовуємо іiї в електронних записниках, мобільних телефонах, смартфонах, планшетах, зберігаємо у «хмарах» (англ. Cloud Technology - хмарні технологіï), на серверах тощо.

I тут варто звернути увагу на такі процеси: робота набуває виразних ознак віртуальності; стирається межа між містом і селом (створюється т. зв. світове село); збільшення чисельності користувачів соціальних мереж зумовлює, 3 одного боку, розширення поверхневих контактів, зв'язків, зустрічей, з іншого - посилення не особистісних начал, а індивідності, відокремленості, ізольованості: люди ховаються за ніками (нікнеймами), аватарами, псевдонімами; погіршуються навички й уміння роботи зі складною інформацією і довгими текстами; формується снек-культура (англ. snack легка закуска) - ми на ходу їмо, п'ємо, перевдягаємося, розв'язуємо питання, спілкуємося, робимо мейк-ап, шукаємо стосунків без шлюбних зобов'язань, кохаємося, народжуємо та виховуємо дітей, робимо кілька справ одночасно тощо. Вочевидь, 
людина відчуває бажання не просто мати, а мати швидко і легко, не докладаючи зусиль, без зайвих хвилювань й обтяжливих наслідків, і це на тлі прямолінійної, доволі агресивної й адресної маркетингової кампанії, скерованої на швидке отримання задоволення (від їжі, напоїв, одягу, сексу тощо) тут і зараз.

Як наголошує Мануель Кастельс, технологія не зумовлює розвиток суспільства, але ж і суспільство не визначає напрям технологічних змін. Щойно інформаційні технології розповсюдились і були засвоєні різними державами, культурами, організаціями з різними цілями, вони відразу засвідчили вибуховий розвиток у всіх галузях прикладного використання, підживлюючи за рахунок зворотного зв'язку технологічні інновації, прискорюючи їх темпи, розширюючи зону технологічних змін і диверсифікуючи їх джерела [9, с. 28-29].

Людина власне і відрізняється від тварини тим, що має особливі риси, притаманні саме їй. Ідеться не про мавпу з вибухівкою, адже людина здатна усвідомлювати міру та межу між корисним і шкідливим, зважувати всі «pro et contra». Даний нам вогонь, ми здавна використовуємо 3 практичною метою. Він зігріває, допомагає приготувати їжу тощо, але водночас може спричинити пожежу, знищуючи все живе, або завдати іншої шкоди. Так само обережно потрібно використовувати й упроваджувати ІКТ, тобто до змін, які відбуваються в суспільстві внаслідок стрімкого впровадження в усі галузі діяльності людини IКТ та інших технічних засобів, не варто ставитися негативно.

На часі формування образу людини майбутнього, що можливе завдяки новій освітній парадигмі, у якій ІКТ із засобу поневолення перетворяться на засіб звільнення, чого можна досягти, як уважає Сергій Смирнов, шляхом зміни нашої онтологічної ідентичності. 3 огляду на це він обстоює: зміну пріоритетів і спрямування зусиль не на знищення, а на збереження людини; формування нового образу людини майбутнього, що твориться нею самою; нову антропологію, нове розуміння людини на зміну віджилим конструктам і концептам минулих часів, які (конструкти та концепти) i штовхають сучасну людину до суїцидального стану (тут йдеться про феномен кіборга, прикріплення до людського тіла штучних виробів), які згодом перетворюються на вбивць); створення і розповсюдження нових антропопрактик, за допомогою яких формується ця перетворювана людина. Ці антропопрактики мають бути масовим явищем і задавати тренд, здатний протистояти тренду відходу. Саме тому потрібно: формувати духовний зір; висувати нову антропологічну альтернативу; розробляти й упроваджувати такі способи існування, які стимулюють людину піклуватися про саму себе та про середовище свого існування; змінювати онтологічну ідентичність людини; вчитися керувати антропологічними трендами (діагностика, моніторинг, аналітика, ініціація антропологічної альтернативи, розробка й упровадження нових антропопрактик, спрямованих на антропологічне самовизначення - повернення людини вже не до природи (як у некласичний період наукового знання), а до самої себе й до інших (постнекласичний період)) [21, с. 10].

3 огляду на вищезазначене важливе місце серед ключових компетентностей Учителя (Викладача), розвитку й удосконаленню яких приділяється особлива увага, посідає компетентність, пов'язана з його інформаційною і комунікаційною діяльністю.

Потрактування поняття «ІКТ» не можна зводити лише до засобів, адже йдеться також і про технології - 3 їх синкретизмом, нерозривністю техніки, технологій та особливих форм мислення, що відбивають обов'язкову присутність людини. На думку Акопа Назаретяна, існує закон техногуманітарного балансу: чим вища міць виробничих і бойових технологій, тим більш досконалі засоби культурної регуляції необхідні для збереження суспільства [17, с. 99], тобто всі технічні досягнення мають узгоджуватися 3 етичним і моральним складником людської діяльності. Функціонування ІКТ також 
підпадає під дію цього закону. Наразі, на наше переконання, ІКТ мають виступати як система теорій, ідей, засобів і методів організації освітньої діяльності, скерованих на ефективне розв'язання проблем, що охоплюють усі аспекти засвоєння знань i формування практичних умінь і навичок; вони спонукають до неперервної самоосвіти, а сам процес навчання дає можливість оцінити практичні результати, так і мережа, складовими якої $\epsilon$ учасники освітнього процесу (Вчителі (Викладачі) й Учні (Студенти)), без яких використання ІКТ як таке втрачає сенс.

Розглянемо позитивні й негативні аспекти off-line освіти як системи й on-line освіти як мережі.

До позитивних аспектів off-line освіти як системи належить віднести такі: загальна й обов'язкова для всіх освіта 3 єдиним навчальним планом і програмами; систематичність і логічність у викладі матеріалу, що сприяє дисциплінованості; поступовості у вивченні предметів; сприйняттю системних взаємозв'язків між поняттями і предметами тощо. Негативні аспекти пов'язані з тим, що класно-урочна система позбавляє особистість можливості вільно розпоряджатися своїм часом; нав'язує i підпорядковує знання, значно зменшує ініціативність; через економікополітичну необхідність готує людину-гвинтика, тому що розвиненій промисловості для отримання прибутків потрібні не самостійні працівники, а інструменти, які мають бути пунктуальними, слухняними, пасивними, здатними виконувати конкретно поставлені завдання, готовими сприймати своє незадовільне становище як належне. Вузькоспеціалізована праця, задовольняючи вимоги індустріального виробництва, тяжіє до посилення політики «сильної руки». Додаткова вартість складає невелику частку прибутку.

Натомість, on-line освіта як мережа має сприяти свободі вибору, розвитку ініціативності, когнітивної сфери, розширювати коло спілкування, привчати людину до самоосвіти впродовж усього життя. Проте on-line освіта як мережа має свої негативні аспекти: великий обсяг інформації, який Учень (Студент) має засвоїти; втрата здатності до зосередження і постійного концентрування уваги на одному предметі; негативний вплив ІКТ на стан здоров'я тощо. 3 огляду на зазначені тенденції традиційні методи та прийоми не завжди, а іноді взагалі не будуть ефективними у навчальному процесі. I тут стає очевидним теоретико-методологічний дисбаланс, що змушує фахівців з різних галузей налагоджувати взаємозв'язки між цими підходами та шукати шляхи виходу 3 кризи. Одним із таких шляхів, на наше переконання, може стати впровадження у навчальний процес нових технологій, методів і методик.

Уважаємо за доцільне зазначити, що у вітчизняному освітньому i науководослідницькому дискурсі проблема інноваційних методів навчання залишається однією 3 найбільш актуальних. Іншим нагальним питанням $\epsilon$ проблема співіснування двох освітніх парадигм: off-line освіти як системи й on-line освіти як мережі. Розглянемо більш докладно, які саме сучасні інноваційні технології використовуються в них.

У сучасній off-line освіті як системі Вчителі (Викладачі) застосовують такі інноваційні методи і методики розвитку когнітивної сфери Учнів (Студентів), як: структурування тексту у вигляді таблиць, TASC-аналіз, «Fishbone», стратегія «INSERT», cinquain, coaching тощо. Стисло проаналізуємо їх.

Структурування тексту у вигляді таблиць дає змогу Вчителям (Викладачам) i Учням (Студентам) активно і плідно працювати у системі суб'єкт-суб'єктних відносин, пов'язувати зміст тексту зі своїм особистим досвідом («знаю, хочу знати, дізнався»), допомагає виробити власну позицію з досліджуваної теми.

TASC-аналіз є 10 послідовно поставленими запитаннями, над якими під час читання тексту Учням (Студентам) належить міркувати [16, с. 18]. Співпраця між Учителем (Викладачем) і Учнем (Студентом) налагоджується тоді, коли читач (Учень 
(Студент)) починає пропонувати ідеї, що доповнюють, оцінюють або ставлять під сумнів аргумент, наведений автором (Учителем (Викладачем)).

«Fishbone» сприяє встановленню причинно-наслідкових взаємозв'язків між об'єктом аналізу і суб'єктом, який його вивчає, спонукає до обгрунтованого вибору, дозволяє формувати й удосконалювати вже існуючі навички роботи з інформацією й уміння ставити та розв'язувати проблеми.

«INSERT» («Умовні позначки») має на меті навчити такого сприйняття навчального матеріалу, у процесі якого інформацію, що іiі отримує Учень (Студент), можна розуміти, сприймати, зіставляти 3 особистим досвідом i на цій підставі формулювати власне аналітичне судження.

Сінквейн (фр. cinquains, англ. cinquain) - це творча робота, яка має форму короткого вірша і складається 3 п'яти неримованих рядків. Він сприяє концентрації знань, асоціацій, почуттів; звуженню оцінки явищ і подій; формуванню своєї позиції, погляду на подію чи предмет; умінню виокремлювати в навчальному матеріалі найбільш істотні навчальні елементи, робити висновок і висловлюватися стисло.

Коучинг (англ. coaching - готувати, тренувати, co-achievement - спільне досягнення) - це процес взаємодії Вчителя (Викладача) і Учня (Студента), що має на меті допомогти людині розкрити власний потенціал, визначити найбажаніші для себе цілі й досягти їх із застосуванням найбільш ефективних засобів.

Вищенаведені методики сприяють розвитку когнітивної сфери Учня (Студента) шляхом концентрування уваги на предметі дослідження, скеровують його в майбутнє; орієнтують на фахове самовизначення, формують готовність самостійно робити вибір, приймати рішення і нести відповідальність за наслідки; підтримують мотивацію, допомагають у подоланні психологічних перешкод на шляху до мети; надають інформацію щодо проблеми, окреслюють цілі, шляхи та засоби їх досягнення, сприяють залученню до роботи у групах і їі організації; розвивають критичне мислення; візуалізують взаємозв'язки між причинами й наслідками; здійснюють ранжування чинників за їх значущістю, зменшуючи тим самим негативні моменти, які існують у off-line освіті.

На свідомість Учня (Студента), як наголошує Наталія Кочубей, тисне хаотичний потік інформації, що надходить з телебачення, Internet-y, переважаючи над знаннями, отриманими від батьків, вихователів, Учителів (Викладачів), і відкриваючи нескінченні можливості для різних стосунків, зв'язків, дій. Ці процеси спричиняються до формування «кліпової свідомості». До того ж Учителі (Викладачі) та психологи зауважують виникнення «мовчазного дитинства», «оніміння мови», «зростаючого мовчання» як наслідків самотності Учнів (Студентів) перед екраном телевізора або монітором комп'ютера. При цьому їхнє мовлення стає жахливо збіднілим, незважаючи на широкі можливості отримання інформації [10, с. 17]. Отже, з одного боку, йдеться про перспективи щодо збільшення обсягу і піднесення якості інформації, з іншого, неможливість розібратися в потоці інформації та неспроможність використати їі.

Постає проблема формування культури ставлення до ІКТ, усвідомлюється складність у переході від мозаїчного мислення до цілісного сприйняття дійсності. I у цьому процесі провідне місце має належати перш за все Вчителям (Викладачам), які будуть спроможні зробити цей процес більш гнучким, ефективним i менш травматичним для Учнів (Студентів). Учитель (Викладач) за допомогою впровадження та використання IКТ упродовж навчального процесу має допомогти Учням (Студентам) впоратися 3 цією проблемою. Розглянемо, які сучасні інноваційні технології впроваджуються у освітній процес у оn-line освіті як мережі.

Мережеві технології - сучасний напрям інформатизації суспільства загалом й освіти зокрема, що бурхливо розвивається. Найбільшою глобальною мережею, що 
об’єднала тисячі регіональних і корпоративних мереж світу, $є$ Internet - сукупність різних складників: електронної пошти, електронних підручників, словників, довідників, енциклопедій, телеконференцій і навіть чатів, блогів, Wiki-Wiki тощо [3, c. 9]. Тут можна використовувати такі методи та методики: гейміфікацію; інкапсуляцію; LMS, хмарні технології тощо.

Практика гейміфікації (англ. gamification) пов'язана із застосуванням підходів, характерних для ігор, у неігрових ситуаціях з метою залучення користувачів i споживачів до розв'язання прикладних завдань, споживання продуктів, послуг. Ї̈̈ мета - емоційне залучення, заохочення й утримання уваги учасників. Для цього можуть бути використані різні методики: розвиток віртуальних навичок, шкали прогресу, рейтингова система, створення ігрового персонажа, поступове відкриття нових навчальних елементів. Дроблення освітнього курсу на посильні «квести» дозволяє привернути увагу користувачів, дарує відчуття перемоги з кожним виконаним блоком вправ, а прив'язка завдань до реальних цілей Учня (Студента) нівелює відчуття безглуздості виконуваних вправ.

Переваги цього методу полягають у залученні й утриманні уваги Учнів (Студентів) і підвищенні їх мотивації. Гейміфікація може допомогти подолати рутину і спонукати до навчання: поставити глобальну мету, зафіксувати віхи на шляху до неї (рівні в грі), забезпечити постійне унаочнення прогресу (бали, бонуси), соціальний супровід (дошка лідерів, можливість розповісти про власні успіхи), логічне зростання рівня складності (нові складні завдання), додаткові випробування і різноманітний досвід для підтримання інтересу (виступи, написання статей тощо), краще засвоєння знань і підвищення успішності.

Провідний принцип гейміфікації - забезпечення постійного, вимірюваного зворотного зв'язку з гравцем, що вможливлює динамічне коригування його поведінки; це, своєю чергою, сприяє швидкому опануванню всіма функціональними можливостями гри й поетапному зануренню в неї. Провідна мета ділиться на більш дрібні цілі, завдання - на підзавдання, що дозволяє відстежувати свій прогрес. Позитивні емоції, що їх отримує Учень (Студент) у процесі навчання, спонукають його до подальшої роботи, наближаючи до реальної практичної діяльності. Типові варіанти навчання в ігровій формі включають у себе сценарії і проблеми, які змушують Учнів (Студентів) обирати, мають різні наслідки і результати, моделюють ситуації в практичній площині, що наближає навчання до реального життя [18].

До основних елементів ігрового процесу, що їх можна і варто використовувати 3 освітньою метою, належать:

- прогрес - наочне відображення поступового зростання (рівні складності гри, які відкривають i розширюють доступ до контенту, бали, за допомогою яких визначають значущість виконаної роботи);

- задоволення від гри (досягнення, тобто публічне визнання завершення роботи; нові завдання, які можна отримати на вході в систему; спільна робота для досягнення цілей; отримання значних результатів; віртуальність для залучення нових гравців);

- поступове відкриття інформації (бонуси як несподівані винагороди; зворотний відлік, що стимулює до виконання завдання впродовж обмеженого часу; дослідження свого освітнього оточення і набуття нових знань; запобігання втраті того, що вже зароблено; безперервна гра для досягнення експертного рівня; синтез знань під час розв’язання завдань, що вимагають застосування відразу кількох навичок [25].

Поряд $з$ перевагами використання геймфікації існують і деякі проблеми: Учень (Студент) не розуміє, чому цей метод навчання або цей сервіс кращий за аналоги, йому нудно просто читати / переглядати матеріал і виконувати завдання, поступово він 
втрачає бажання продовжувати навчання, ігнорує тести й письмові завдання, не підтримує зворотний зв'язок.

Наведемо приклади сервісів, які використовують гейміфікацію для освіти: Codecademy - навчання програмуванню на Java Script, HTML, Python, Ruby; Code School, Motion Math Games - мобільні ігри з математики; Mathletics - програма для шкіл 3 математики та челленджі; Khanacademy - безкоштовні відеокурси 3 різних дисциплін; Spongelab - платформа для персоналізованої наукової освіти; Foldit розв'язання наукових завдань за допомогою пазлів.

Інкапсуляція - це механізм, який об'єднує дані й методи, що маніпулюють цими даними, захищаючи те й інше від зовнішнього втручання або неправильного використання. Коли дані й методи об'єднуються у такий спосіб, створюється об'єкт. Застосовуючи інкапсуляцію, ми ніби зводимо фортецю, яка захищає дані, що належать об'єкту, від можливих помилок, які можуть виникнути в разі прямого доступу до цих даних. Попри це, застосування зазначеного принципу дуже часто допомагає локалізувати можливі помилки в коді програми, а це набагато спрощує процес пошуку і виправлення цих помилок.

LMS (Learning Management System, LMS) використовується для розробки й поширення навчальних on-line- матеріалів із забезпеченням спільного доступу до них i управління ними, поєднуючи в собі функції викладання, навчання, оцінювання й управління освітніми курсами [24].

Хмарні технології (Cloud Technology) дають користувачам Internet-у доступ до комп'ютерних ресурсів сервера і програмного забезпечення (on-line-сервіси) [22].

Змішане навчання (blended learning) - це система навчання / викладання, яка поєднує найбільш ефективні аспекти викладання в аудиторії й інтерактивного або дистанційного навчання та $\epsilon$ системою, що складається 3 рівних частин, які функціонують у постійному взаємозв'язку одна з одною, утворюючи певне ціле. Це система, складові якої гармонійно взаємодіють за умови, що всі вони методично доцільно організовані.

Дослідники Галина Чередніченко та Людмила Шапран виокремлюють три основні моделі змішаного навчання, які поширені в сучасному освітньому середовищі:

- очне навчання (face-to-face) $€$ традиційним форматом аудиторних занять Учитель (Викладач) - Учень (Студент);

- самостійне навчання (self-study learning) передбачає самостійну роботу Учнів (Студентів): пошук матеріалів за допомогою ресурсної карти, пошук у мережі та ін. [6];

- on-line навчання (on-line collaborative learning) - робота Учнів (Студентів) i Вчителів (Викладачів) у режимі on-line, наприклад, за допомогою Internetконференцій, Skype, Wiki тощо [23].

Засобами досягнення навчальних цілей за методикою змішаного навчання $є$ два типи навчальних платформ:

- зовнішні платформи, змістове наповнення яких індивідуально розробляє навчальна інституція з урахуванням мети навчання і потреб Учнів (Студентів) (наприклад, Moodle, Web Course Tools);

- внутрішні платформи, що відображають зміст уже розроблених навчальних курсів (наприклад, Mackmillan English Campus, CALL) [15].

Перевагами змішаного навчання є: своєчасне виявлення Учнів (Студентів), які зазнають труднощів під час вивчення навчального матеріалу (більшість сервісів змішаного навчання включають on-line-інструменти, які дають негайний зворотний зв'язок Учителеві (Викладачеві) з Учнем (Студентом)); широкий вибір матеріалів і завдань, що підходять для конкретного класу, індивідуальний підхід до кожного класу; 
ефективне використання часу на уроці. За змішаної системи Учні (Студенти) навчаються організовувати і планувати роботу самостійно, незалежно отримувати й аналізувати знання, шукати та відбирати інформацію, приймати рішення, набувають навички презентації проектів, призвичаюються до самоосвіти.

Однак, незважаючи на явні переваги, модель змішаного навчання має цілу низку недоліків, до яких можна віднести небажання багатьох Учителів (Викладачів) здійснювати електронне навчання, низький рівень володіння технологіями як Учителів (Викладачів), так і Учнів (Студентів), залежність від техніки й Internet-y. Тут варто наголосити, що впровадження змішаної форми навчання справді вимагає від Учителя (Викладача) досить значних зусиль [12, с. 21-22].

Отже, модель змішаного навчання цілком вписується в концепцію модернізації сучасної освіти, що грунтується на впровадженні нових освітніх стандартів i приєднанні до Болонського процесу й інших міжнародних угод. Зазвичай, упровадження змішаної форми навчання вимагає певних змін у нормативно-правовій базі, інвестицій у розробку необхідного навчального контенту і перепідготовки кадрів. Але, без сумніву, у тій складній ситуації, у якій нині опинилась освіта, назріла необхідність революційної модернізації всієї освітньої галузі, коли ІКТ мають створити новий експериментальний простір, де Вчителі (Викладачі) та розробники освітніх технологій зможуть апробовувати новий педагогічний i методологічний інструментарій, включаючи автоматичне оцінювання, інтерактивні симулятори й освітні ігри. Про це свідчить і виступ міжнародного радника з питань освітніх систем та інновацій Кена Робінсона (англ. Ken Robinson) на TED Talks: «Усі сучасні системи освіти перебувають на етапі реформування, але цього недостатньо, реформа нині вже не $\epsilon$ дієвою, бо вона покликана вдосконалити модель, яка не працює. Нам потрібна не еволюція, а революція в освіті. Система має перевтілитись у щось нове» [20]. На нашу думку, йдеться про нову парадигму освіти як унаочнення концепції навчання впродовж усього життя (Life Long Learning).

Потрібно зазначити, що на сучасному етапі розвитку України через складне економічне становище, пов'язане із занепадом економіки і сільського господарства (промисловість і аграрний сектор уже не потребують великої кількості освічених кадрів), виникла криза всієї освітньої галузі, яка призвела до зменшення кількості спочатку загальноосвітніх, а згодом й вищих навчальних закладів і скорочення штатів науково-педагогічних працівників. Тому актуалізується проблема пошуку альтернативних методик і технік викладання матеріалу, що сприятимуть реалізації творчого потенціалу в умовах жорсткої конкуренції між Учителями (Викладачами).

У процесі активного i цілеспрямованого розвитку творчого потенціалу соціального суб'єкта пріоритетна роль належить саме культурі, освіті та вихованню. Прикро зазначати, але посилення творчої складової навчально-виховного процесу ще не стало нормою в навчальних закладах. Власне стратегія розвитку держави спонукає до дій, і саме проблема творчості вже зараз стає провідною у філософії освіти та виховання.

\section{3. РЕЗУЛЬТАТИ ДОСЛІДЖЕННЯ}

Стратегічною метою освіти i виховання, якій підпорядкований їх зміст $\epsilon$ формування самоорганізованого суб'єкта освітньої діяльності, особистості, спроможної реалізувати себе за умов інтелектуально-творчої свободи шляхом розкриття особливих i неповторних якостей (творчих здібностей), детермінантою яких стає соціально й індивідуально значущий мотив і установка на самореалізацію. Освіта - це процес засвоєння й осягнення інформації, який має ціну і призначення, а відтворені знання 
мають сенс і цінність. Вони виробляються у діалоговому континуумі, у бінарній опозиції «суб' єкт - суб' єкт» освіти й виховання, де, з одного боку, чітко простежується призначення Вчителя (Викладача) (дані терміни вживаються у сучасній науковій літературі здебільшого як синоніми, хоча очевидна їх відмінність: «учитель» - термін, якій частіше вживається у метафізичному сенсі, «викладач» - феномен більш високого порядку, у якому є емоційна складова у формі переживання за свою роль у подальшому житті суб'єкта освіти і виховання, чого бракує в якостях викладача як носія знання), з іншого, - очікується результативність і якісність того, хто виступає в іпостасі іншого суб'єкта освіти й виховання. Саме ця якість і $є$ план творчого порядку, ті здібності, які актуалізуються в індивідуальних особливостях суб' єктів освіти та виховання. До них належать ерудованість, спостережливість, допитливість, воля, критичний склад розуму, працездатність, прагнення до самоосвіти і самовдосконалення, наполегливість у реалізації інтелектуальних планів, оригінальність та ініціативність, комунікативність та інформативність тощо.

\section{4. ВИСНОВКИ ТА РЕЗУЛЬТАТИ ПОДАЛЬШИХ ДОСЛІДЖНЬ}

Проаналізувавши сучасні інноваційні підходи і техніки, що використовуються в off-line освіті як системі й on-line освіті як мережі, ми дійшли висновків, що необхідно змінити життєві пріоритети людства і спрямувати зусилля не на знищення, а на збереження людини (перетворивши ІКТ із засобів, що поневолюють, на засоби, що звільняють), творення нового образу майбутнього, нової антропології, нового розуміння людини завдяки прогресивним антропопрактикам; розробити й упровадити такі способи існування, які спонукатимуть людину піклуватися і про саму себе, і про середовище свого існування; змінити ії онтологічну ідентичність. Усе це зумовило нове розуміння Life Long Learning як сучасної парадигми освіти, яка постає на межі off-line освіти як системи й on-line освіти як мережі. Отже, структура й сутність інноваційного потенціалу освітнього процесу має повною мірою відповідати характеру і швидкості соціальних змін, які відбуваються у суспільстві, а також високим європейським стандартам підготовки конкурентоспроможних фахівців інноваційного типу.

До напрямів подальших досліджень відносимо розробку впровадження й використання нових IКТ у навчальний процес задля підготовки висококваліфікованих фахівців інноваційного типу.

\section{СПИСОК ЛІТЕРАТУРИ:}

[1] В. И. Аршинов и В. Г. Буданов, "Системы и сети в контексте парадигмы сложности". Bопросы философии,. № 1,. С. 50-61, 2017. [Электронный ресурс]. Доступно : http://vphil.ru/index.php?option=com_content\&task=view\&id=1555\&Itemid=52.

[2] Ж. Аттали. На пороге нового тысячелетия. Москва. Россия: Междунар. отношения, 1993.

[3] Н. Р. Балик та О. О. Лялик, Активне навчання з використанням технологій Веб 2.0 : навч. посіб. Тернопіль. Україна : Навч. книга - Богдан, 2009.

[4] С. О. Ганаба. Філософія дидактики: контексти, стратегї̈, практики : монографія.- Суми. Україна : Університетська книга, 2015.

[5] Ж. Делёз. Логика смысла. Москва. Россия: Академический Проект, 2011.

[6] Е. В. Желнова. 8 этапов смешанного обучения (обзор статьи «Missed Steps» Дарлин Пейнтер. Training \& Development). [Электронный pecypc]. Доступно : http://www.obs.ru/ interest/publ/?thread=57.

[7] Инновационная сложность. "Парадигма сложности в перспективе философской стратегии Жиля Делёза. Материалы «круглого стола»", Философия науки и техники. Т. 21, № 2, с. 149-181, 2016.

[8] М. Кастельс. Галактика Интернет: Размылиления об Интернете, бизнесе и обществе. Екатеринбург. Россия: У-Фактория (при участии изд-ва Гуманитарного ун-та), 2004. 
[9] М. Кастельс. Информациионая эпоха: экономика, общество и культура. Москва. Россия: ГУ ВШЭ, 2000.

[10] Н. Кочубей, "Дитина в сучасній інформаційній культурі : проблеми добра і зла". Вісник Інституту розвитку дитини. Сер. : Філософія, педагогіка, психологія. Вип. 29. С. 15-19. 2013. [Електронний ресурс]. Доступно: http://nbuv.gov.ua/UJRN/Vird_2013_29_5.

[11] В. Кремень та В. Ткаченко. "Ціннісні орієнтири мережевого суспільства". Психологія особистості, № 1 (4), c. 7-20, 2013.

[12] О. Кривонос та О. Коротун, "ішане навчання як основа формування ІКТ-компетентності вчителя" Наукові записки. Серія: Проблеми методики фізико-математичної і технологічної освіти, Вип. 8, (11). С. 19-23 [Електронний ресурс]. Доступно : http://eprints.zu.edu.ua/19412/1/Kryvonos.pdf.

[13] В. А. Кутырёв. Бытие или ничто. Москва. Россия. - Берлин. Германия. : Директ-медия, 2015.

[14] В. А. Кутырёв. Последнее ичелование. Человек как традиция. Санкт-Петербург. Россия : Алетейя, 2015.

[15] Н. О. Микитенко, "Ефективні методики формування іншомовної професійної компетентності майбутніх фахівців природничих спеціальностей", Наукові записки Тернопільського національного педагогічного університету імені Володимира Гнатюка. Серія : Педагогіка, № 2, с. 157-166, 2011.

[16] А. Л. Муравьева, Ю. Н. Кузнецова и Т. Н. Червякова, Организачия модульного обучения, основанного на компетенциях : пособие для преподавателей. Москва. Россия: Альфа-М, 2005. [Электронный ресурс]. Доступно: https://alterozoom.com/en/documents/17593.html

[17] А. П. Назаретян, "Воспитательный потенциал синергетики: гипотеза техно-гуманитарного баланса" Научный результат : сетевой науч.-практ. журнал. Серия : педагогика и психология образования, № 2, с. 98-105, 2014. [Электронный ресурс]. Доступно : http://rrpedagogy.ru/media/pedagogy/2014/2/Назаретян_АП.pdf.

[18] "Преимущества геймификации" [Электронный ресурс]. Режим доступа : http://lms.smartme.university/ blog/igraj-i-vyiigryivaj-preimuschestva-gejmifikatsii/

[19] Р. Рабинович. Тенденции в on-line образовании [Электронный ресурс]. Доступно: http://theoryandpractice.ru/videos/1064-roman-rabinovich-tendentsii-v-onlayn-obrazovanii.

[20] I. Рахмістрюк. "Чи відбудеться революція в українській системі освіти?" , Zn, иa. 16 січ. 2015. [Електронний ресурс]. Доступно: http://gazeta.dt.ua/EDUCATION/chi-vidbudetsya-revolyuciya-vukrayinskiy-sistemi-osviti-_.html.

[21] С. А. Смирнов, \#Антропология номадизма (Антропологические тренды и северный культурный код)", Человек, № 3, с. 5-17, 2014.

[22] "Хмарні технології в навчанні" Інфосвіт : освітній портал [Електронний ресурс]. Доступно : http://infosvit.if.ua/hmarni-tehnolohiji-v-navchanni/.

[23] Г. А. Чередніченко, Л. Ю. Шафран, Модель змішаного навчання $і$ ї̈ використання у викладанні іноземних мов. [Електроннй ресурс]. Доступно: http://2015.moodlemoot.in.ua/course/view.php?id=83\&lang=en.

[24] A User-Friendly, Intuitive Learning Management System [Online]. Available: https://www.docebo.com/learning-management-system-lms/

[25] Education Infographics. Knewton [Onfine]. Available:: https://www.knewton.com/\%20infographics/gamification-education/

[26] P. Virilio, The Lost Dimension, New York, USA : Semiotext(e), 1991, 152 p.

Матеріал надійшов до редакиії 12.03.2017 p.

\title{
ТЕХНОЛОГИЧЕСКИЕ АСПЕКТЫ СТАНОВЛЕНИЯ НОВОЙ ОБРАЗОВАТЕЛЬНОЙ ПАРАДИГМЫ
}

\author{
Кныш Инна Васильевна \\ $\mathrm{PhD}$, доц. кафедры ДПД и украиноведения \\ Сумской национальный аграрный университет, г. Сумы, Украина \\ ORCID ID 0000-0003-4194-1555 \\ knysh_sumy@ua.fm
}

\section{Кочубей Наталья Васильевна}

доктор философских наук, профессор, заведующая кафедрой менеджмента и инновационных технологий социокультурной деятельности

Национальный педагогический университет имени М. П. Драгоманова, г. Киев, Украина

ORCID ID 0000-0003-3668-7193

n.v.kochubey@ua.fm 


\begin{abstract}
Аннотация. Выяснено, что на постнеклассическом этапе развития образования в Украине сложились две образовательные парадигмы, а именно: off-line образование как система и on-line образование как сеть, имеющие свои преимущества и недостатки. Обосновано, что теоретико-методологический дисбаланс, возникший между этими парадигмами, обусловил переосмысление Life Long Learning как новой образовательной модели. Проанализированы современные инновационные техники и методики, которые используются в данных образовательных парадигмах. Доказано, что ИКТ - это средство не порабощения, а освобождения, которого можно достичь благодаря созданию и распространению новых антропопрактик, преследующих цель возвращения человека не только к самому себе, но и к другим. Отмечено, что внедрение ИКТ должно способствовать самоорганизации, самопознанию и самосовершенствованию личности как Ученика (Студента), так и Учителя (Преподавателя).
\end{abstract}

Ключевые слова: новая парадигма образования; Life Long Learning; ИКТ; off-line образование как система; on-line образование как сеть; смешанное обучение; Ученик (Студент); Учитель (Преподаватель); антропопрактики; постнеклассика.

\title{
TECHNOLOGICAL ASPECTS OF ESTABLISHING A NEW EDUCATIONAL PARADIGM
}

\author{
Inna V. Knysh
}

$\mathrm{PhD}$, associate professor of the Faculty of State Law and Ukrainian Studies

Sumy National Agrarian University, Sumy, Ukraine

ORCID ID 0000-0003-4194-1555

knysh_sumy@ua.fm

\author{
Nataliia V. Kochubei \\ Doctor of Philosophy, Professor, Head of the Department of Management and \\ Innovative Technologies of Social and Cultural activities \\ National Pedagogical Dragomanov University, Kyiv, Ukraine \\ ORCID ID 0000-0003-3668-7193 \\ n.v.kochubey@ua.fm
}

\begin{abstract}
The study shows that two educational paradigms have been established at the current stage of Ukrainian education, namely, off-line education as a system and on-line education as a network; their advantages and disadvantages have been outlined. The author has grounded that theoretical and methodological disbalance between these two paradigms brought about the appearance of a new understanding of Life Long Learning as a new paradigm of education. The article provides analysis of modern innovative techniques and methods used in the educational paradigms. It has been grounded that ICT cannot be considered as a means of enslavement but rather a means of liberation which can be reached due to the production, processing and distribution of new anthropopractices that will facilitate the return of a man to himself and to others. ICT should encourage self-organization, self-cognition and self-improvement of a personality of Learner (Student) as well as Teacher (Educator).
\end{abstract}

Key words: a new paradigm of education; Life Long Learning; ICT; off-line education as a system; on-line education as a network; blended learning, Learner (Student); Teacher (Educator); anthropopractices; postneclassics.

\section{REFERENCES (TRANSLATED AND TRANSLITERATED)}

[1] V. I. Arshinov, and V. G. Budanov, "Systems and networks in the context of paradigm of complexity", Questions of Philosophy, no. 1, pp. 50-61, 2017. [Online]. Available: http://vphil.ru/index.php?option=com_content\&task=view\&id=1555\&Itemid=52 Accessed on: April 20, 2017. (in Russian)

[2] J. Attali, On the threshold of the new millennium. Moscow: Mezhdunar. otnosheniya, 1993. (in Russian)

[3] H. P. Balyk, Active learning by using Web 2.0 technologies. Ternopil: Navchalna knyha - Bogdan, 2009. (in Ukrainian) 
[4] S. O. Hanaba, Philosophy of didactic: contexts, strategies, practices: monograph. Sumy: Universytetska knyha, 2015. (in Ukrainian)

[5] G. Deleuze, The Logic of Sense. Moscow: Akademicheskii Proekt, 2011. (in Russian)

[6] "Innovative complexity. The paradigm of complexity in the perspective of the philosophical strategy of G. Deleuze. Materials of the "round table", Philosophy of Science and Technics, vol. 21, no. 2, pp. 149181, 2016. (in Russian)

[7] Ye. V. Zhelnova, "8 stages of blended learning (the review of the article «Missed Steps» by Darlin Peynter)", Training \& Development. [Online]. Available: http://www.obs.ru/interest/publ/?thread=57 Accessed on: May 25, 2017. (in Russian)

[8] M. Castells, The Internet Galaxy: Reflections on the Internet, Business, and Society. Yekaterinburg: UFaktoriya, 2004. (in Russian)

[9] M. Castells, Information era: economy, society and culture. Moscow: GU VSHE, 2000. (in Russian)

[10] N. Kochubey, "A child in today's information culture: the problem of good and evil". Bulletin of the Institute of a Child's Development, Series: Philosophy, Pedagogy, Psychology, issue, 29, pp. 15-19, 2013. [Online]. Available: http://nbuv.gov.ua/UJRN/Vird_2013_29_5 Accessed on: April 15, 2017). (in Ukrainian)

[11] V. Kremen, and V. Tkachenko, "Values of the network society", Psychology of Personality, no. 1(4), pp. 7-20, 2013. (in Ukrainian)

[12] O. Krivonos, and O. Korotun, "Blended learning as a basis of forming teacher's ICT-competence", Scientific notes, Series: Problems of methodology of education in physics and mathematics, issue 8 (11), pp. 19-23, 2015. [Online]. Available: http://eprints.zu.edu.ua/19412/1/Kryvonos.pdf Accessed on: May 20, 2017). (in Ukrainian)

[13] V. A. Kutyryov, Being or Nothingness. Moscow - Berlin: Diret-media, 2015. (in Russian)

[14] V. A. Kutyryov, Last kissing. Man as tradition. St. Petersburg: Aleteiya, 2015. (in Russian)

[15] N. O. Mikitenko, "Effective methods of forming foreign language professional competence of prospective specialists of natural specialities", Scientific notes of Ternopil Volodymyr Hnatyuk National Pedagogical University, Series: Pedagogy, no. 2, pp. 157-166, 2011. (in Ukrainian)

[16] A. A. Muravyova, Yu. N. Kuznetsova, and T. N. Chervyakova, Organization of modular learning based on competences. Moscow: Alfa-M, 2005. [Online]. Available: https://alterozoom.com/en/documents/17593.html Accessed on: April 21, 2017. (in Russian)

[17] A. P. Nazaretyan, "Educational potential of Synergetics: hypothesis of the tech-humanitarian balance", Scientific result, Series: Pedagogy and Psychology of Education, no. 2, pp. 98-105, 2014. [Online]. Available: http://rrpedagogy.ru/media/pedagogy/2014/2/Назаретян_АП.pdf Accessed on: April 21, 2017. (in Russian)

[18] Advantages of gamification. [Online]. Available: http://lms.smartme.university/blog/igraj-i-vyiigryivajpreimuschestva-gejmifikatsii/ Accessed on: May 25, 2017. (in Russian)

[19] R. Rabinovich, Tendencies in on-line education. [Online]. Available: http://theoryandpractice.ru/videos/1064-roman-rabinovich-tendentsii-v-onlayn-obrazovanii Accessed on: April 17, 2017. (in Russian)

[20] I. Rakhmistryuk, "Will there be a revolution in Ukrainian education?”UA Zerkalo nedeli, @zn_ua, January 16, 2015. [Online]. Available: http://gazeta.dt.ua/EDUCATION/chi-vidbudetsya-revolyuciya-vukrayinskiy-sistemi-osviti-_.html Accessed on: April 20, 2017. (in Ukrainian)

[21] S. A. Smirnov, "Anthropology of nomadism (Anthropological trends and the northern cultural code)", Man, no. 3, pp. 5-17, 2014. (in Russian)

[22] "Cloud technologies in teaching", Infosvit: Educational Portal. [Online]. Available: http://infosvit.if.ua/hmarni-tehnolohiji-v-navchanni/ Accessed on: April 18, 2017. (in Ukrainian)

[23] H. A. Cherednichenko, and L. Yu. Shapran, "Blended learning model and its use in teaching foreign languages". [Online]. Available: http://2015.moodlemoot.in.ua/course/view.php?id=83\&lang=en Accessed on: May 27, 2017. (in Ukrainian)

[24] A User-Friendly, Intuitive Learning Management System. [Online]. Available: https://www.docebo.com/learning-management-system-lms/ Accessed on: May 5, 2017.

[25] Education Infographics. Knewton Infographics. [Online]. Available: https://www.knewton.com/\%20infographics/gamification-education/ Accessed on: June 5, 2012.

[26] P. Virilio, Lost Dimension. New York. USA: Semiotext(e), 1991.

\section{(cc) BY-NC-SA}

This work is licensed under Creative Commons Attribution-NonCommercial-ShareAlike 4.0 International License. 